\title{
Control of Audiences through Information Communication Technology in the Perspective of Communication Psychology
}

\author{
Syafrizaldi \\ Faculty of Psychology, Universitas Medan Area, Indonesia \\ Email: syaf.rizaldi.csr@gmail.com
}

\begin{abstract}
:
This journal discusses audience control through information and communication technology in the perspective of communication psychology through studying phenomena with a literature approach. Information and communication technology (ICT) is capable of providing a controlling effect for individuals and society. In fact, from 2014-2019 there were mass actions carried out by a group of masses. Some have named it the MUI Fatwa Guard National Movement (GNPF-MUI) Action 411 and 212 until the mass action which took place on May 22, 2019 and on September 26, 2019. Various news has spread through the sophistication of information and communication technology through media applications social facebook, instagram, whatsapp information spreads so massively. This has an effect on controlling the behavior of individuals and communities (audiences), so that so many audiences who are exposed to information are unable to stem and carry out searches related to the information obtained, resulting in behavior in accordance with the expectations of the information disseminators. In this case it can be concluded that the effect of media can affect perceptions, down to the aspects of affection and behavior. Communication psychology provides a relevant understanding perspective related to these various phenomena. Individuals and societies when using information and communication technology involve perceptions, memories, needs, values, attitudes, motives, motivations, personality, knowledge, emotions, skills and personal and social interpretations. Thus it can be concluded that information and communication technology in use today can have an impact on audiences in aspects of perception, affection, and behavior. So without realizing it information technology can be used for the benefit of various individuals or groups in controlling audiences.
\end{abstract}

Keywords:

control; audience; information and communication technology; communication psychology

\section{Introduction}

Currently, there are almost no humans who do not use information and communication technology. At a minimum, people have technological media such as television. In its development, humans always provide meaningful changes to their lives and lives. One of the characteristics of society in the modern era 4.0 is its closeness to technology. Even technology is a necessity that creates dependency for today's society. In all their activities, people take advantage of technological sophistication such as cleaning the house, preparing food, washing and so on.

The progress of information technology is very influential in life (Lubis and Buana, 2020). Including how people have a need in terms of communicating and getting information immediately. So that created an information technology that is designed with high technology. In its development, information technology has introduced mobile phones (cellphones) to communicate with fellow humans, which in its appearance eroded landlines and telephone stalls 
(wartel). Then developed communication media created by humans to convey various information. According to Dewi et al (2019) Media represents in portraying the communication. Robin in Nuraflah (2020) states that communication is more than just conveying meaning, but more than that, communication is a process of understanding.

The development of information and communication technology that occurs today has generated a positive response from the government. This has been proven by the Indonesian government through several efforts, one of which is the 2014-2019 Indonesian Broadband Plan (RPI) which is stated in Presidential Regulation Number 96 of 2014.Broadband or broadband is internet access with guaranteed connectivity that is always connected, guaranteed durability and information security, and has triple-play capability with a minimum speed of $2 \mathrm{Mbps}$ for fixed access and $1 \mathrm{Mbps}$ for mobile access. Thus, it is hoped that it will support the growth of national development and Indonesia's competitiveness at the global level, as well as improve the quality of life of the Indonesian people "(Bappenas, 2014).

Then there was a leap in the advancement and sophistication of information and communication technology. Today's mobile phones are even more advanced. Technology develops in line with the demands of society's own needs. Then a variety of applications emerged in a set of communication tools, namely smartphones. A smartphone that is in the grip of an individual is like a double-edged knife, which can have positive benefits, but on the other hand, it can be threatening and frightening to humans themselves.

In reality, information communication technology has changed behavior patterns and the way people interact with others. It is so easy for people to connect with one another by a communication information technology anytime and anywhere. This gave birth to a new human civilization. Information communication technology is present as something extraordinary. Practically and efficiently all human needs can be fulfilled by using current technology.

However, we cannot deny that the presence of increasingly sophisticated communication information technology actually presents universal problems in life. With a single press, any information that the public conveys through a set of devices they have will arrive very quickly to other people (audiences). Especially at this time developing the phenomenon of information or news that is shared through information communication technology systems. Some are true, some are not right, some are good and some are not good. So that the term hoax (fake news) is very familiar in today's society.

Then, The current picture is that human behavior changes along with the development of information and communication technology. The easier it is for individuals or societies that are consciously or not controlled by information and communication technology. Several events that have occurred today in the period between 2016 and 2019 have reported that a group of people are busy buying certain products, people with light steps flock to meet political events or events that often lead to crowd control / society to act excessively, anarchically and so on based on the intentions and interests of a group. Starting from the 411 and 212 action events to the actions that took place on 22 May 2019 and 26 September 2019.

Thus, it can be concluded temporarily that how information communication technology today is able to influence, change and control audiences or society in accordance with the aims and objectives of the presenters or information disseminators. 


\section{Review of Literatures}

Control means a process or method of controlling action (KBBI). Control is an attempt to achieve certain goals through expected behavior (Mulyadi. 2007). The word control is often used in the context of management in organizations. However, in this case this journal will present a terminology from a communication point of view whose designation is used in the framework of the use of information and communication technology.

Meanwhile, what is meant by audience is defined as "audience". Historically, it comes from the word audire which means to hear in Greek (Whitney, 2009). In the Big Indonesian Dictionary, audience is defined - one of them - as "a particular group in society who is the target of communication". However, it can be said that approaching the concept of audiences is easier through the character of the audience itself than through a standard definition. Why? Because humans who in this context are attached to the word audience (audiences) always undergo development, not static but not always dynamic, sometimes passive and also with advances in technology the audience becomes active.

Technology is a system for doing something to meet human needs with the help of tools and reason (Hardware and Software) as if to extend, strengthen, or make the limbs, senses and brain more powerful. Whereas information is the result of processing, manipulation, and organizing or structuring from just a group of data that has knowledge value for its users (Sutabri (2014). Abdul Kadir (2003) states that information technology includes hardware and software to carry out one or a number of data processing tasks such as capturing, transmitting, storing, retrieving, manipulating or displaying data. First, capturing data is the process of a server being able to receive signals generated from other servers via waves / intermediaries to get data. second, transmitting data is a process for sending data from one of the data sources to the data recipient using a computer / electronic media, so that the data is easily accepted and understood by others (Abdul Kadir, 2003).

We must realize, information communication technology is basically still technology. Despite the benefits for our lives, technology is never neutral. Apart from promoting instrumental values such as efficiency, safety, reliability and convenience, technology should also promote substantive socio-moral-political values such as freedom, justice, enlightenment, privacy, and autonomy. However, the latter will not happen automatically, but must be actively strived for in its design (Flanagan, Howe \& Nissenbaum, 2008).

In addition, the relationship between humans and technology is also mediated by various dimensions that accompany it, such as: history, culture, community, division of tasks, and roles (Rückriem, 2009). That is, the relationship between humans and communication information technology is no longer adequate if it is only seen as an impersonal and exclusive relationship. Users are individuals who when utilizing information and communication technology involve perceptions, memories, needs, values, attitudes, motives, motivations, personalities, knowledge, emotions, skills and interpretations that are personal and social. These psychological attributes are then framed in the existential contradictions of human psychology, between us and us (Hassan, 2014).

Talking about communication psychology, looking at information and communication technology that has an influence on its ability to control audiences as described above, the writer tries to provide a communication psychology perspective in looking at these problems. Through an explanation of the effects of mass media presence written in a mass psychology book (Rakhmat. 2005). 
There is the relevance of psychological concepts in looking at the phenomena described above, that the audience can unconsciously control their thoughts and behavior with the sophistication of information and communication technology that has developed so far. The presence of mass media from time to time raises complex and varied phenomena. The review submitted by Rusdi Muchtar in 1979, highlighted the phenomenon of shifting their routine habits due to the presence of television media at that time. Likewise what happened in America, as stated by Schramm, Lyle and Parker (1961) showing how the presence of television has reduced the time to play, sleep, read and watch movies. And several studies related to it were also carried out in England and in Japan (in Rakhmat, 2005).

If you look at the phenomenon of demonstration actions that have occurred recently (2016-2019), as described at the beginning of the presentation of this journal, the audience who receives information through massive social media is reported, which is then used as a basis for attitudes and resistance them in the form of massive demonstrations. This basically has a connection between the effects of mass media and the emergence of the expected behavior by a person or group of people according to the objectives to be achieved.

\section{Discussion}

Information and communication technology is a broad terminology that includes all technical equipment for processing and conveying information. Information and communication technology includes two aspects, namely information technology and communication technology. Information technology includes all matters relating to the process, use as a tool, manipulation and information management. Meanwhile, communication technology is everything related to the use of tools to process and transfer data from one device to another. Therefore, information technology and communication technology are two inseparable concepts. So Information and Communication Technology contains a broad definition, namely all activities related to processing, manipulation, management, transfer of information.

There are facts that give us an idea that from several demonstrations carried out in the last few years $(2014$ - 2019) it is a reality that information and communication technology has taken part in mobilizing the mass actions that have taken place. The facts that occurred during the 411 and 212 demonstrations held by the GNPF Ulama were a form of social movement. A social movement is a movement that can have an impact on the progress of a nation or even vice versa. Jhon McCarty and Mayer Zald define social movements as organized efforts to bring about changes in the distribution of things that are socially valuable (Prismamudti, 2018).

If we look back, the emergence of the 411 and 212 actions stems from the circulation of information through social media which is widely reported that the governor of DKI Jakarta Basuki Tjahaya Purnama (Ahok) has committed acts of blasphemy against the religion of Islam by saying that "it could be in your little heart, Ladies, I didn't choose me because I was lied to by (people) using all kinds of Surat Al Maidah 51. That is the right of you. If you feel you can't choose because you are afraid to go to hell, you will be fooled, that is, oh that's okay, because this is your personal call. ". This statement made Muslims flustered and considered that Ahok had insulted Islam. 
This created a wave of actions called the MUI Fatwa Guard National Movement (GNPF-MUI) Action 212 which coincided on December 2, 2016.From tracing the facts that developed before the action took place, it presents the role of information and communication technology developing today. became the catalyst for the wave of action that was able to bring millions of people to gather at Monas at that time. This proves that the mindset and audience perceptions can be influenced by the sophistication of information and communication technology. Information that travels through social media is then consumed into cognitive processes and through affective power which is based on the same fate, in accordance with the creation of a sense of solidarity among communities by the majority of people in Indonesia which then affects perceptions, even the behavior of audiences that have been unconsciously controlled by the acceptance of this information through social media as a result of the development of information communication technology.

The interesting thing is that it turns out that the flow of news information related to the issue of religious blasphemy that was carried out until the 411 and 212 actions were not significantly correlated with the activity on Facebook of the figures who drove the 411 and 212 Actions did not have an influence on the formation of solidarity of action participants. Based on more in-depth research through the interview method, it is known that the solidarity of the 411 and 212 Action participants is more influenced by private media, such as WhatsApp Group (Priliantini and Damayanti, 2018).

Then, of course, we still remember the event where a massive demonstration took place on May 22, 2019. Due to the government's difficulty in banishing the massive news about the demonstration spread on social media such as Facebook, WhatsApp, the government unilaterally took action by turning off access. the social media application network. Once again, this proves that the role of social media is a form of information communication technology development that can be used as a tool for the movement of many audiences in social and political aspects in this country.

Not only that, in the news in the mass media detiknews reported on September 26, 2019 with the title; "Circulating Message Invitation to a Demo for Junior High School Students in Brebes". Explained that: Two grade IX students of SMP Negeri 3 Brebes respectively with the initials RA and HA admitted to joining the demonstration because of an invitation from a friend through the WA application. This invitation message is read at home, after returning from school. Then there was a situation where a number of students had gathered to demonstrate against the revision of the KPK Law and the Criminal Code Bill in various cities, including Brebes. Then kompas.com (on September 28, 2019) also reported that there had been a demo invitation to students who was sent via message on the existing Whatsapp application.

Seeing the phenomena described above, the authors can formulate an overview of the audience control strategy, namely; 1 . Today's audience control is very massive by relying on communication channels using internet technology databases that present the development of information and communication technology so that news dissemination occurs so fast. 2. In delivering information to the public, the presentation of information uses the agenda setting approach. 3. That in order to provide an emotional and ideological control effect on audiences, the most effective disseminators of information use a social media channel called whatsapp (WA) / whatsapp group, because this social media is widely used by audiences in the form of their respective group spaces. 
The effect of mass media in the study of communication psychology is discussed in three aspects. First the cognitive aspect. In this case the mass communication effect is described in terms of images. Image in this case is defined as a personal map of the world. Image is the world according to our perception. Robert (1977) states that communication does not directly lead to certain behaviors, but tends to influence the way we organize our image of the environment and this image affects the way we behave (Rakhmat, 2005).

Likewise mass communication. We will begin to examine the cognitive effects of communication on image formation and alteration. The second is the affective effect of mass communication. In 1960, Joseph Klapper reported the results of a comprehensive study of the effects of mass media. In relation to the formation and change of attitudes, the influence of mass media can be summarized in five general principles, namely; a. the influence of mass communication is mediated by factors such as persona predisposition, selective processes, group membership (or what in this book is called personal factors). b. Due to these factors, mass communication usually serves to strengthen attitudes and opinions, although sometimes it functions as an agent of change. Third, when mass communication causes a change in attitude, Small changes in attitude intensity are more common than "conversion" (change of whole attitude) from one side of the problem to the other. Fourth, mass communication is quite effective in changing attitudes in areas where public opinion is weak, for example in commercial advertising. Then the fifth, mass communication is quite affective in creating opinions about new problems when there is no predisposition that must be confirmed (Oskamp, 1977).

Although affectionately, the results of previous studies (Walter Weiss, 1969) show very little evidence that shows the effect of mass media on changing attitudes. However, if examined in the agenda setting theory, the mass media influence in terms of influencing the prominence of an issue above other issues (In McGuire, 1969). Then the third is the behavioral effect of mass communication. In this case we see the mass media as merely a physical object. Here we look at the effect of mass media messages on audience behavior. This section discusses more theories that explain the effects of mass communication on social events.

The psychological theory that can explain the prosocial effects of mass media is Bandura's social learning theory. According to Bandura, we learn not only from direct experience, but from imitation or modeling. Behavior is the result of cognitive and environmental factors. Bandura describes the social learning process in four stages of the process; the attention process, the retention process, the motoric reproduction process, and the motivational process. According to Bandura, events that attract attention are those that stand out and are simple, occur repeatedly, or cause positive feelings to the observer (that is, satisfy their psychological needs), Rakhmat (2005).

Furthermore, Rakhmat (2005) said that attention alone is not enough to produce psychosocial effects. The audience should be able to keep their observations in mind and recall them when they will act according to the example set. Delayed modeling only occurs when they are able to remember the events they observed. According to Bandura, in order for that event to be emulated, we not only have to record it in memory, but also be able to mentally imagine how we can perform the actions we emulate. Visualizing ourselves doing something is called "rehearsal". 
According to Rahkmat (2005) the next process is a motoric reproduction process which means reproducing the behavior or action we observe. But whether we actually practice exemplary behavior depends on motivation. Motivation hinges on affirmation. There are three kinds of affirmations that encourage us to act, namely; external affirmation, vicarious reinforcement and self-affirmation. Something that we will do if other people don't appreciate and don't criticize what we are doing (external affirmation). Then we will continue to do this behavior if we see other people doing the same thing too (alternation confirmation). And if we ourselves encourage that action or behavior, the source is when there is satisfaction, pleasure (self-affirmation).

From the aforementioned description, we can see that audience control which is influenced by information and communication technology media in principle follows the psychological approach patterns as described. This also refers to the concept that when information received through social media such as YouTube, Facebook and or Whatsapp is conveyed to audiences where the dissemination of information is conveyed so much and repeatedly delivered, this will have an effect on the appearance of audience behavior in accordance with what is wanted by those who convey this information through the sophistication of information communication technology that is developing today as in the previous author's explanation regarding audience control through information communication technology.

\section{Conclusion}

In reality, information communication technology has changed behavior patterns and the way people interact with others. It is so easy for people to connect with one another by a communication information technology anytime and anywhere. This gave birth to a new human civilization. Information communication technology is present as something extraordinary. Practically and efficiently all human needs can be fulfilled using today's sophisticated technology.

In explaining the phenomenon of audience control through information and communication technology, in principle it is related to a mass communication theory approach, namely the agenda setting theory which explains that mass media is able to influence audience perceptions of what people think, succeeds in convincing and shaping perceptions and what thought of the audience. To the point of causing behavior in accordance with the objectives of the party delivering the information.

A psychological perspective can also provide a basis for how the role of mass media in controlling audiences can also be explained through a social learning theory outlined by a character named Albert Bandura. According to Bandura, we learn not only from direct experience, but from imitation or modeling. Behavior is the result of cognitive and environmental factors. Bandura describes the social learning process in four stages of the process; the attention process, the retention process, the motoric reproduction process, and the motivational process. The four stages run unconsciously by the audience to give rise to attitudes and behaviors in certain forms.

Audience control which is influenced by the information and communication technology media in principle follows the psychological approach patterns as described. This also refers to the concept that when information received through social media such as YouTube, Facebook and or Whatsapp is conveyed to audiences where the dissemination of information is conveyed so much and repeatedly delivered, this will have an effect on the 
appearance of audience behavior in accordance with what is desired by those who convey this information through the sophistication of information and communication technology that is developing today as in the previous author's explanation regarding audience control through information and communication technology.

\section{References}

Ajeng Iva Dwi Ferbriana. (2018). Determinisme Teknologi Komunikasi dan Tutupnya Media sosial path, jurnal lontar vol.6 no 2 juli-desember 2018

Anjang Priliantini ${ }^{1}$ dan Damayanti². (2018). peran media sosial "facebook" dalam membentuk solidaritas kelompok pada aksi 411 dan 212. Jurnal Komunikasi, Media dan Informatika, Vol. 7 No. 1 /April 2018.

Anita Septiani Rosana ; Kemajuan Teknologi Informasi dan Komunikasi dalam Industri Media di Indonesia

Ahmad Zaenudin (2017). Mengenang Friendster dan Media Sosial Jadul yang Lain

Bappenas. (2014). Rencana pitalebar Indonesia 2014-2019. Jakarta: Pengarang.

Baran, Stanley J. And Davis, Dennis K. 2012. Penerjemah S. Rouli Manulu. Pengantar Komunikasi Massa, Melek Media dan Budaya. Jakarta: Erlangga.

Cohen, Bernard C. (1969). The Press and Foreign Policy, 3th ed , New Jersey :Princeton University Press.

Dewi, N., R., et al. (2019). Moodle Cloudas the Developing Listening E-Learning Media in SMP Negeri 7 Medan. Britain International of Linguistics, Arts andEducation(BIoLAE) Journal, 272-277.

Fusch, Christian. (2017). Social Media: A Critical Introduction 2nd Edition. SAGE Publication Ltd. California.

Hastjarjo, Sri. (2012). Literasi Media Baru Berbasis Local Wisdom Jawa. Yogyakarta. ASPIKOM.

Hassan. (2014). Psikologi dan Teknologi Informasi/editor. J. Seno Aditya Utama. Et.al. Jakarta. Himpunan Psikologi Indonesia.

Ibadullah Malawi, M.Pd, Dewi Tryanasari, M.Pd, Apri Kartikasari HS, M.Pd. (2017). "Pembelajaran literasi berbasis sastra local". EA Media Grafika. Magetan.Jawa Timur

Iswandi Syahputra. (2017). "Demokrasi virtual dan perang siber di media sosial:perspektif netizen Indonesia". jurnal aspikom, volume 3 nomor 3, juli 2017.

Jalaludin Rakhmat. (2005). Psikologi Komunikasi. PT. Remaja Rosdakarya. Bandung.

Kharisma Nasionalita. Relevansi Teori Agenda Setting Dalam Dunia Tanpa Batas dalam Jurnal Ilmiah Komunikasi |MAKNA Vol. 5 no. 2, Agustus 2014-Januari 2015 yang ditulis oleh Kharisma Nasionalita.

Lubis, S., Buana, R. (2020). The Influence of Technology and Information on Student's Behavior: a Case Study of SMA Negeri 1 of Pantai Cermin at Serdang Bedagai. Britain International of Humanities and Social Sciences (BIoHS) Journal, 523-528.

McGuire. (1969). The Nature of Attitudes and Attitude Change", The Handbook of Social Psychology, G. Lindzey dan E. Aronson, Editor, Reading: Addison-Wesley.

Mulyadi. (2007). Sistem Perencanaan dan Pengendalian Manajemen. Jakarta: Salemba Empat.

Mc Quil, Dennis. (2011). Teori Komunikasi Massa. Edisi Terjemahan, Jakarta; Salemba Humanika.

Mannhem, dalam Nurudin. (2007). Pengantar Komunikasi Massa, Jakarta: Raja Grafindo Persada.

Nawiroh Vera. (2016). Komunikasi Massa. Penerbit Ghalia Indonesia.Bogor.

Nuraflah, C., A. (2020). The Communication Strategy of Government in Bulu Cina Village towards Prosperous Village. Britain International of Humanities and Social Sciences (BIoHS) Journal, 374-380. 
Oskamp. (1977). Attitude and Opinions, Englewood Cliffs : Prentice-Hall, Inc.

Sutabri, Tatang. (2014). Pengantar Teknolo-gi Informasi. Yogyakarta: ANDI.

Siti Utami Prismamudti, 2018 Strategi Komunikasi GNPF MUI Dalam Menggalang Massa.

Wira Respati. (2014). Transformasi media massa menuju era masyarakat informasi di Indonesia. humaniora vol.5 no.1 April 2014.

Whitney, D. C. (2009). Audience. In J. Steele (Ed.), Encyclopedia of Journalism (pp. 126-131). Los Angeles: SAGE Publications.

West, Richard dan Lynn H. Turner. (2011). Pengantar Teori Komunikasi Analisis dan Aplikasi. Edisi 3 Buku 2 jakarta; salemba Humanika.

Wilson, T. (2009). Understanding Media Users from Theory to Practice. Malden, MA: John Wiley \& Sons, Ltd.

https://www.kompasiana.com; indonesia-krisis-literasi-di-era-revolusi-industri-4-0. Diakses tanggal 24-10- 2019

https://www.maxmanroe.com.” Arti Literasi: Pengertian, Tujuan, Manfaat, dan Jenis-Jenis Literasi /vid/umum/arti-literasi-adalah.html. diakses tanggal 24-10-2019 